\title{
Writing Africa, Righting America: An Experience of Otherness in J. P. Clark's America, their America
}

Adewuyi Aremu Ayodeji

University of Ilorin, Ilorin, Nigeria (M. A. in Literature-in-English)

ORCID ID: 0000-0002-4246-8934

\begin{abstract}
Considered one of the finest first-generation Nigerian writers, John Pepper Clark-Bekederemo, who passed away on 13th October, 2020, had been categorised as a Eurocentric writer. This work assesses the authenticity or otherwise of this critics' perception of Clark by critiquing his America, their America. By analysing this autobiography vis-à-vis the notion of self and other which is a theoretical concern in contemporary travel writing, it was established, among other things, that every culture has its dark sides which it must not feel too proud to change as time and situation demand; that Clark vehemently rejects the Americans' claim of sophistication and superiority of their culture over African culture. The paper concludes that contemporary travel writing should be a rightful site for negotiating cultural, political and diplomatic compromises between the Self and the Other since the gulf may be difficult to close altogether.
\end{abstract}

Keywords: Eurocentric; autobiography; travel writing; culture; diplomatic 


\section{Writing Africa, Righting America: An Experience of Otherness in J. P. Clark's America, their America}

\section{Introduction}

If my elementary knowledge of biology is anything to go by, then movement is one vital characteristic of all living things. For humans, legs become the natural tools for performing this locomotive action. But knowing full well that there is a limit to where the two legs can carry one, the primitive man devised other means of easing and lengthening movement. Animals like horses, camels, etc. then served the purpose for man. This extended movement of humans is termed transportation. Man's inquisitiveness could be said to have actually propelled him to fashion out other transportation means which would make travelling easier and much more enjoyable. Aside from man's curiosity for travelling, Anjum (2014) gives other reasons to include "...diplomacy, political pursuit, military campaigns, trade, business contacts, exile, flight from persecution, migration, pilgrimage, missionary activities, and the search for economic or educational opportunities..." (191). As a matter of exigency, man wanted to tenaciously explore the world beyond his birthplace; hence, he resorted to travelling for relaxation, exploration etc. This establishes for us the rationale behind man's continuing love for travelling.

Travel entails breaking the barrier of border erected to confine man to a limited space at a specific point in time. According to Thompson (2011), "To travel is to make a journey, a movement through space" (9).A multidisciplinary genre, travel writing has been depicted by Raban (1988) as: "notoriously raffish open house where different genres are likely to end up in the same bed. It accommodates the private diary, the essay, the short story, the prose poem, the rough note and polished table talk with indiscriminate hospitality. It freely mixes narrative and discursive writing" (Anjum, 2014: 192).Travel writing is also viewed as the umbrella term for travelogue, travel book, book of travels, travel novel (Anjum, 2014). It thus "...subsumes works of exploration and adventure as well as guides and accounts of sojourns in foreign lands..." (Anthony, 1977: 715).Travel writing, even though reflects the time and space of the writer's sojourn, by no means entails a chronology of plot as the account of a journey in this wise goes beyond mere logging of dates and events (Winspinski, 1997).

Although travel writing is not a new genre, it has not always enjoyed the much-needed attention of literary critics. Whereas Anthony (1977) asserts that the earliest accounts of travels came from Egypt as exemplified by the anonymous 14th B. C. record, The Journey of the Master of the Captains of Egypt, travel writing actually became an instrument for literary scholarship in the late 1990s. The rise in the literary status of travel writing is traced to the latter part of the twentieth century (Thompson, 2011: 2). Until the turn of the last decade of the twentieth century, "...the genre was usually dismissed by literary critics and cultural commentators as a minor, somewhat middle-brow form" (Thompson, 2011: 2). Wispinski (1997) states that "...the low value generally placed on travel writing has been lack of scholarship on the subject" (p. 1). He 
also quotes Michael Kowalewski as proposing that "the "dauntingly heterogeneous character" of the travel genre has kept literary critics away" (p. 1). However, the serious exposure of travel writing to literary scholarship and its subsequent rise in reputation came about "...with the appearance of a new generation of critically acclaimed travel writers such as Paul Theroux, Bruce Chatwin, Ryszard Kapuscinski and Robyn Davidson" and the searing efforts of "...the prestigious British literary journal Granta, which ran several travel-themed special issues in the 1980s and 1990s..." (Thompson, 2011: 2).

Thompson (2011) goes further to identify five major factors that have contributed to the recent popularity of travel writing among literary critics and academic scholars: (1) the assumption (by Granta) that travel writing is a genre especially reflective of, and responsive to, the modern condition" (p. 1); (2 "Scholars and students working in several different disciplines have found the genre relevant to abroad range of cultural, political and historical debates". These debates are primarily occasioned by 'postcolonialism' or 'postcolonial studies' which aims “...to comprehend, and to contest, the pernicious consequences of the vast European empires of the nineteenth and early twentieth centuries", and feminism through which "...critics have investigated women's contribution to a genre that superficially seems strongly associated with men..." (pp. 2-3); (3) the conception that "...modern travel writing can yield significant insights into the ideologies and practices that sustain the current world order" (p. 3); (4) "The genre has also featured in literary studies in debates about canonicity, and the relationship between aesthetic and functional forms of writing..." (p. 3); (5) "In social sciences such as Geography, Anthropology and Sociology,..., the recent interest in travel writing is partly a consequence of theoretical and methodological debates as to the forms of knowledge and enquiry most appropriate to each discipline" (p.3).

Soumani (2012) also classifies factors that have made scholars from diverse academic disciplines pay critical attention to travel writing in recent times into two:

...first, the current geopolitical context, in which such notions as "mobility," "displaceme nt," "identity," "border," etc., linked to the concept of travel itself become central and give (sic) rise to questions which can be addressed more efficiently when different perspectives and methodological outlooks come together to engage in inquiry. The second factor is more directly related to the genre of travel writing in itself, which, as Joan-Pau Rubiés puts it, is more adequately described as a "genre of genres": "a variety of kinds of literature defined by a variety of purposes and conventions share travel as their essential condition of production. (p. 1)

While Soumani (2012) has potently reiterated some of the points raised by Thompson (2011) and other critics, his mention of some specific terms, beyond the larger literary scale of postcolonialism and feminism, that form the thematic thrust of modern travel writing underlines the uniqueness of his submission. 
Adams et al. (2011) discuss some of the features of travel writing which made it "...emerge(d) as one of the most popular, if not the most popular, literary genre among nineteenth-century U.S. readers" (p. 25). According to Adams et al. (2011), critics such as Justin Edwards have emphasised the socio-cultural significance of travel writing in the U.S., focusing particularly on its "...meaningful blend of entertainment and education", its ability to draw out "...the desire of readers for knowledge regarding the foreign and the exotic", its functionality as the only vehicle for engaging the deep-rooted fascination a perceived difference in tradition held for the nineteenth-century citizen, and its erection of " ...a foundation of knowledge on foreign locales and populations" which "...offered individual readers an opportunity to negotiate his/her position within the ever-shifting political landscape of the nation" (25).Not only do they identify travel writing as an agent of socialization which aided "...the westward expansion of the U.S. throughout the nineteenth century", Adams et al. (2011) contend that the textual encounter of the readers of these travel narratives with foreign figures "...encouraged their readers to think through their own national, racial, and gendered identities" (25).

\section{Demonisation of Travel Writing}

For its role as one of the tools in establishing and further reinforcing or expanding the European Empire in the nineteenth and early twentieth centuries, travel writing has always been under biting criticism of the former colonised people. To put it metaphorically, travel writing is viewed by a good number of postcolonial critics as a confirmed demon of hegemony. Edwards and Graulund (2011) portray this idea better: "In the field of postcolonial studies, travel writing has often been demonized" (1). Their conclusion hinges on the fact that "Critics have, at times, aligned travel narratives with other textual practices associated with colonial expansion mapping, botany, ethnography, journalism and so on - to suggest that travel writing disseminated discourses of difference that were then used to justify colonial projects (Edwards and Graulund, 2011: 1). Their argument specifically suggests that travel writing, together with the other textual practices mentioned, was complicit in advancing discourses which promoted colonialism. This allegation is not without some proof. In the U.S. for instance, travel writing was said to have served as a vehicle for westward expansion in the nineteenth century (Adams et al., 2011).

Truly, it is not easy for the postcolonial critic to 'forgive' travel writing for its alleged 'crimes' against the colonies and the colonised. The early nineteenth century writers of travel narratives always deservedly and carelessly celebrated the western culture over and above that of the foreign people they had met on their journeys. This they mostly did not just to claim the supremacy and sophistication of European/western culture, but to subjugate the indigenous people whom they usually described as savages, heathens, etc. and deprive them of their natural resources (Thompson, 2011). Satapathy (2012) affirms that "Since the narration of travel certainly so in the eighteenth and nineteenth centuries - is controlled by European hegemony, there is a clash between authenticity and imagination" (4). This clash, stemming from cultural devaluation of other people, that permeated the travel narratives of the time, makes Thompson 
(2011) say: "The ideological dimensions of travel writing, and the larger rhetorical purposes served by the frequent tendency of travel writers to depict other groups and cultures in a hostile or condescending way, are topics that have been much addressed in the recent wave of travel writing studies" (134).Thus, particularly for its complicity in the propagation of hegemonic enterprise (Posti, 2014), travel writing cannot be completely 'exonerated' from the evils of colonialism, and that is one point which still renders it unpopular among some postcolonial critics.

In working out a theoretical framework for this paper, two books caught my attention. First, Orientalism (1978) written by foremost postcolonial critic and theorists Edward Said. In the book, Said (1978) explicitly (re)defines the ideological base of imperialism (what he calls orientalism) as the socio-cultural gulf between the Orientals (the colonised, e.g. the East) and the Occidents (the coloniser/Europeans). According to him, the term 'Oriental' "...designated Asia and the East, geographically, morally culturally" (Said, 1978: 31).With this delineation of geopolitical orbit, "The western countries looked upon the orientals as people of inferior kind, they are poor uncivilized, immoral, dirty. Such views may at times be...presented by the west through literature, paintings, films or other forms of artistic expression" (Ranjan, 2015: 85). That (mis)representation of the colonised's culture and geography 'marred' the earliest travel narratives. Said believes that "Some particular attributes were associated with the orientals, and whatever the orientals weren't the occidents were" (Rajan, 2015: 86). So, in Orientalism, we are confronted with the notion of dichotomy between the Self (the Orientals) and the Other (the Occidents). It is, therefore, this same notion that I attempt to explore in J.P. Clark's America, their America. This task I also carry out having in mind Thompson's (2011) definition of travel as "...the negotiation between self and other that is brought about by movement in space" (9). It is hoped that this exercise will help shed more light on the personality of Clark who, together with Wole Soyinka and Christopher Okigbo, was labelled a Eurocentric writer (Chinweizu et al., 1980).

The second was Debbie Lisle's (2006) The Global Politics of Contemporary Travel Writing. The book establishes the nexus between modern travel writing and the world politics. In the words of Lisle,

This book politicizes travelogues by revealing their connection to the 'serious' business of world affairs, and their significance to the study and practice of global politics. It argues that the quasi-fictional genre of travel writing is at least as useful for understanding issues of international importance as the policy documents, government press releases, parliamentary debates and media stories that are usually privileged in this context. (Lisle, 2006: 1)

Unlike other postcolonial critics who would not 'forgive' travel writing, Lisle (2006) attests to the importance of the genre in the modern world. She supposes that travel writing "...has the 
potential to re-imagine the world in ways that do not simply regurgitate the status quo or repeat a nostalgic longing for Empire" (xi). Her argument and wish is that travel writing in the contemporary time "...can be resuscitated as a crucial site for political debate and resistance" (276). This is why I strongly believe that critiquing the socio-political discourses raised in J. P. Clark's America, their America still remains relevant.

\section{Negotiating the Self in America, their America}

Although Said's (1978) Orientalism centres around the West's (mis)perception of the East as an inferior people, his concentration on the distinction between the orientals (the East) and the occidients (the West) generalises the notion of the Self and the Other. This notion is overtly incorporated into J. P. Clark's America, their America. In the whole work, the writer unsuccessfully endures a battle of the Self and the Other. As much as the Americans attempt to condemn his 'queer' African culture, the writer questions many American ways of life seemed contrary to the African values. This portrays him as an incorrigible African man who would always censure the perceived rot in American system. The writer, then a young Nigerian playwright and journalist, had gone on a one-year journey to America for the Parvin Fellowship programme at the Princeton University. He had not only used the opportunity to travel round the various regions of the country, he had also taken his time to study the society, its people, its cultural values, and form his own opinion of them. In narrating his experiences and pinpointing the crucial issues, Clark does not deny the work its aesthetic flavour. He rather deploys necessary aesthetics to address the issues of racial discrimination, American dream, culture conflict, America's generosity and his regrets.

The kaleidoscopic structure of New York City at first held a fascination for Clark. In contrast with the eyesore in his newly independent country, Nigeria, all the steel and glass structures as well as skyscrapers gave New York City more beauty. His close examination of these well-planned structures made him conclude: "Undoubtedly, my first impressions of America as seen through the city of New York were overlush and typical of the jungles from which I understood I had just emerged" (Clark, 1964: 19). Here, he gives an objective perspective on his own part of the world, referring to it (Africa) metaphorically as "the jungles". But London, where he had landed the night before, seemed far more clean and organised.

Having got himself acclimatised to the civilised world, he began to find fault with the (dis)organisation of the city. This sees him aligning himself with and finally appreciating African setting. Now conscious of the hazards that came with the artificial design of the city, he reduced New York City to a mere warehouse and machine factory in a poetic form:

Steel, stone, glass boxes! Not one

A carton

To handle with care! 
Castellated, crowd

Mile on end, fall one

Over the other, and Europe State, the proud

Above this nightmare

Of ladders, beams, bolts, fumes, refuse...(19-20)

Clark, in the poetic description, employs synecdoche, i.e. he uses parts of the city's buildings to represent the whole city of New York. This way, the city becomes an artificial architectural design which can be taken down piece by piece. He also slams the overcrowding experienced on the streets of New York.

To buttress his perception of the city as an artificial design, he "writes off the great iron heap in rather funeral terms":

The skyscrapers and

Bridges, among the avenues

And Isles, are pyramids

And aqueducts, cutting

Swathes on a tired ground

Saddling streams running to sand. (21)

Like an epitaph, the verse mourns (or rather mocks) the city for its fake architectural constitution, i.e. decking tombs with fresh flowers and flying flags which made it difficult to distinguish which structure was for the dead and which for the living. Clark portrays the city of New York as a dead entity. This is a paradox, meaning the gradual death of nature in the city (America) and abundance of same in his "jungles" (Africa). He truly believes America's artificiality bestows glamour on the continent; yet, Africa still boasts of crude nature. What Africa lacks in glamour, it makes up for such in nature.

Racial discrimination which makes equity in America a mirage takes the larger part of the story. Clark highlights this as one of the obvious vices in the American polity, civilisation and belief system. This forms the writer's subtext in the work. Clark presents America as a society rife with politics of colour: the whites are fond of abasing the blacks. He reveals that even within the American circle, the notion of the Self and the Other still plays out. The blacks constitute the Other in the American scheme of things. To show the high rate of discrimination against the blacks, Clark quotes President John Kennedy as saying: "The Negro baby born in America today, regardless of the section or state in which he is born, has about one-half as much chance of completing high school as a white boy, born in the same place, on the same day; one third as much chance of becoming a professional man; twice as much chance of becoming unemployed... (55)". This indicates that even the government was aware of the miserable condition the Negroes (a misnomer for Black Americans) were subjected to in America. They 
"... are long restricted to the lower ranks in the armed forces for no just or legitimate cause" (78). The blacks did not have the same education and employment opportunities as their white counterparts.

Clark admits that America is really "...a white country, with blacks merely there on terms worse than sufferance" (173). This heated utterance he had made because he could not find a black face in the photographs and paintings of America's past and present great presidents and parliamentarians at the Senate and House of Representatives. He wonders if no black man in the land has ever contributed to the growth of America. These photographs, for Clark, are a symbol of white dominance. He calls this an "elimination" strategy - the strategy which as well eliminates the blacks from getting employed even in the theatre of the whites: "Obtaining a regular job on or off Broadway calls for patent assets and of course a certain amount of luck and the right connections. A black skin, however, is a sure liability except of course in those proverbial caste-typed parts of slaves and servants" (115-116).For this singular reason, Negroes also clamoured for a theatre for the black people. To them, theatre was a different world. It was a world where, acting in the meantime the life of the Other being confined to, their quest for justice, equity and freedom could be ascertained in the end.

Clark's visit to the Harlem where his Negro girlfriend, Gloria, lived with her caring mother (Sister) further exposes him to the reality of segregation of the blacks in America. Sister, a metaphor for other members of the black race, is depicted thus:

For hundreds of years, in a land of equal opportunity and freedom, she kept watch, wept and waited; as all her sons were forced out into the field to labour for others to reap the abundant fruit, and for the flogging and worse misfortune has been their wages; as her brothers were hurled out of the house to be hanged from trees or stoned to death without trial for offences as little or non-existence as asking for their birthright or casting an innocent eye on a harlot who happened to be white. (70)

That sums up the unfortunate lot of the black race in America that makes a few of them see Africa as their ancestral home. The wages paid to them did not commensurate with the service they rendered. To worsen this discrimination, black intellectuals and artists, however sound, were rated low in American hierarchy. They were dubbed Negro lawyers, Negro professors, Negro writers, etc. just to belittle their intellect. It is ironical therefore that in a land of equity and justice, inequality and segregation prevail.

In order to stamp out this discrimination, prominent Negro groups sprouted to address the problem. Of them all, the American Society for African Culture (AMSAC) was the most vibrant. Clark, however, noticed some irony in the party organised by the AMSAC where the U.S. Ambassador to the UN, Mr. Adlai Stevenson, was asked to make the first speech. Clark argues that the decision was contrary to the objective of the organisation that purported to defend the 
interest of the blacks by the blacks. Why was then a white man to be asked to present such a speech?

Clark also reflects on the efforts made by black writers to restore the lost glory of the black race. One of such efforts that translated into Negritude of Aime Cesaire and Leopold Senghor, or African Personality of Kwame Nkrumah, was a means of bringing about cultural renaissance so much deserved by the blacks. Clark succinctly and specifically appreciates the artistic efforts of James Baldwin and Langston Hughes (with whom he had some personal interaction). In all of these, Clark thinks of America as a patient in dire need of a cure.

Another weighty issue raised by Clark is the failure of the American dream in the new generation. The term "American dream" is used in diverse ways, but it essentially is an idea that suggests that anyone in the U.S. can succeed through hard work and has the potential to lead a happy, successful life. The roots of American dream can be traced to the American Revolution (Kamp, 2009). It developed out of the need to wean America off European economic tyranny and corruption, and replace such with the ideals of justice and equality. However, inequality rooted in race, class and religion have become the hallmarks of American dream (Kamp, 2009). This raises the question of the lopsided relationship between America (the Self) and the Other.

J. P. Clark also views American dream from a critic's standpoint. On his travels of the different regions of the country, he could see how Americans regurgitated the ideals of American dream. Yet, it is ironical that most Americans did not possess the qualities they preached so passionately. The representative of America and Princeton University, Colonel Robert Van de Velde, Clark's guide, was one of the numerous academics at Princeton who lectured them (Parvin Fellows) on the ideals of American dream. To Clark, such lectures were not expected from a people who celebrated racial discrimination, inequality and injustice. So irritating to Clark were the lectures the Parvin fellows received in the Woodrow Wilson Building on American Civilization that he wondered "...if knowledge of this was all we needed to make us perform our various duties back in our own countries" (121). He utterly challenged the American's hypocrisy of claiming wrong is right.

Clark's allusion to Alexis de Tocqueville's book, Democracy in America (1831-1832), is aimed at undeniably lauding the good qualities (the American's idea of commerce and trade, his concept of classless society, his belief in equal opportunity, etc.) which the French writer saw in the early founders and pioneers of America. These are good American ideals which actually worked out the founder's dream. Clark condemns the attitude of the new generation of Americans to all these ideals. For instance, he constantly frowned at their romanticisation of capitalism which made them see the nations (like Russia) practising communism as uncivilized. The ideal, perfect political system for the Americans is capitalism while communism is for the Other. 
Two peoples can have different cultures, it is normal; problem arises when one claims to have superiority over the other. It is this claim of cultural superiority by the Americans that Clark could not stomach. He openly challenged the American way of life. In one of his interaction with a group of Americans, he was surprised to hear from actress Marlene: "All my life I have been taught Africans live on treetops among those animals. How should I know you'd be coming to New York to see lions for the first time?" (138). That was the Americans' impression of the Africans: they all live in the jungles with wildlife as their neighbours. They were therefore muddled to hear Clark say he would like to visit a zoo. Marlene's revelation reinforces what Satapathy (2012) terms "...a clash between authenticity and imagination" (4). Clark comes to realise that most Americans lack authentic information about Africa.

On another occasion, Clark argued for polygamy and circumcision before another circle of Americans who saw polygamous marriage as barbaric "...compared to the honourable, democratic practice of co-equal, loving partners observed among American couples" (147). They all intoned, "One man to serveral women deprives the wife of her rights!" (148). Clark explained to them the unmaterialisticnature of the African woman, but was quick to understand that the white woman's rights to her husband's property was just a euphemism for sex which is "...the pre-occupation of most American wives" (148).

Clark as well explained that while the pleasure of sex was the primary concern of the American woman, the African woman was concerned about procreation. The Australian lady he slept with on his first day in America lectured him thus: "Sex to the American...was the twin sister of the Almighty Dollar; and high and low, young and old...over here are all slaves to it. Sex is their highest commodity, and they have made the thing so synthetic and commercial love has become a changeable wave" (25). The writer situates their lasciviousness in the nonchalant attitude of the Americans to circumcision which, to him, "...take(s) care of the itch in the promiscuous!" (148) But the American circle became irritated and viewed it as a form of mutilation.

Moreover, the comfort of the home which made it easy for the Americans to stay indoors without having to visit any relation(s) contrasted with the African communalism. He perceived the trinity of kitchen, telephone and automobiles as factors that made Americans lack the sense of communalism. Of the three, Clark identifies the kitchen as the most treasured and revered by the Americans.

\section{The Self Erred: Regrets, Disappointments and America's Generosity}

The motif of regrets, unfulfilled promises and disappointments pervades the work. At different stages in the course of the narration, Clark dwells on his regrets and unfulfilled promises. Perhaps this makes Childs and Fowler (2006) refer to America, their America as a "...gesture of passionate self-exposure" (21).During his visit to The Home News, he promised to 
show the two girls he had met a Nigerian newspaper but much to his shame, "...the promise was never fulfilled" (45). In another instance, when he visited the Washington Post, Mr. Friendly asked him to visit him again but he didn't and regretted it: "I should have taken advantage of the offer..." (54).

Also, his friend, Dick, tried to convince him that his first and only play, Song of a Goat, be given a 'black' production on the ground that "An African play by a Negro group should therefore make an instant hit" (100). But Clark vehemently objected the idea, saying "...the impression would be that a play written by an African cannot be performed by white people" (100). This is also one of his regrets in America: "...and now that I look back I regret that I rejected Duck's offer of help...I regard it now a great loss of opportunity for work or fun to many" (100).Another unfulfilled promise is seen in his ability to attend the ANTA's production of Bertolt Brecht's Good Woman of Seizuan at which he was supposed to be on the panel. Clark declares that he was disappointed for not being able to make it on the day. It is the same level of regret that he expresses for the aborted proposal from the executive directors of the Columbia Lecture Bureau that he should do a lecture tour of America for them.

In his critical assessment of America's generosity, Clark adjudges the pros and cons of the assistance offered by the U. S. Government and other American organisations to improve the education of developing African countries. The initiative had made it possible for young citizens from Congo, Nigeria and Nyasa to be educated in America. He specifically mentioned the goodwill of the American African Institute with its scholarship scheme, but not without pointing out much brain drain that had resulted from such an initiative. He reacts: "The pity, however, is that these young men and women the Institute carries off every year to the States are some of the brightest products the few secondary grammar schools or senior high schools in the new countries of Africa have to offer to the fewer and newer home universities and colleges" (156).Clark avers that these African students would only be lost to the American culture and not be useful to their home countries. He, thus, suggests giving money to those African countries for building of more universities and colleges would go a long way in preventing brain drain in Africa.

One of the finest of the first generation of Nigerian writers, Clark, whose death was announced on 13th October 2020, had been categorised as a Eurocentric writer (Chinweizu et al., 1980: 163). However, his rejection by the Parvin Fellowship coordinators for his open hatred for anything American makes him appear more African than European. Still, his personality remains questionable in this work. Much as he refused to allow his play, Song of a Goat, to be produced with an all-black cast, he quickly exonerates himself by expressing much chagrin for the action. Why he would not wear African clothes in America throughout his sojourn is also an issue left unexplained. Perhaps like Ashaolu (1978) would defend him, "Clark considers himself as a man of two worlds, a sort of hybrid" (180). 
Finally, of great significance is Clark's objective way of accepting the blame for his eventual uneventful rejection. He puts it thus:

But curse as much as I may still, I do not blame the Colonel for his impatience at last and my unexpected fall.Without riding the image to death, I guess I am what they call aheavy -footed fellow with an excitable turn of temper, and one therefore that would make at all times a poor jockey for the most trusty horse and sanguine backers and owners upon any field. I should be glad of another try! (13)

\section{Conclusion}

America, their America (1964) may have been written long before the publication of Said's (1978) Orientalism and Lisle's (2006) The Global Politics of Contemporary Travel Writing, they all have one thing in common: resisting an imposition of a 'superior culture'. Clark's total refusal to adhere to what he perceived as the rot in, or weakness of, the American culture and his implicit suggestion of African value system as a better alternative embody part of Said's subject matter in Orientalism. This hateful disposition towards American ways of life portrays Clark less as a Eurocentric writer. It is also argued here that, like Lisle (2006) has suggested, America, their America represents a good site for resistance and for political discussion. Indeed, most issues raised in the work cannot be decoupled from the American society of the time of Clark's visit. Unfortunately (and thanks to the writer for accepting the blame for his impatience), Clark failed to see through the negotiation of a compromise between his African culture (the Self) and American culture (the Other).

This paper establishes that contrary to the attitude of most Americans Clark interacted with on his travels of America, no culture is superior to the other. Clark tried in vain to singlehandedly correct this anomaly in culture; in the end, he regrets some of his overreactions including not patiently embracing further dialogue. A difference in culture must not constitute harm to the other people. Justice must favour all people irrespective of their cultural and political affiliations. Every culture has its dark sides which it must not feel too proud to change as time and situation demand. By and large, the paper concludes that contemporary travel writing should be a rightful site for negotiating cultural, political and diplomatic compromises between the Self and the Other since the gulf may be difficult to close altogether. This will timely serve as a sine qua non for striking a balance between opposing cultures of the world. 


\section{References}

Adams, Carolyn, et al. (2011). Travel Literature and History. Houston: Rice University. Connections, http//.cnx.org/content/col11315/1.3/

Anjum, Faraz (2014). Travel Writing, History and Colonialism: An Analytical Study. JRSP, vol. $51(2), 191-205$.

Anthony, Cuddon John (1977). A Dictionary of Literary Terms. London: Andre Deutsch.

Ashaolu, Albert Olu (1978). J. P. Clark: His Significance as Dramatist. In O. Ogunba and A. Irele (eds), Theatre in Africa, pp. 177-199. Ibadan: Ibadan University Press.

Childs, Peter \& Fowler, Roger (2006). The Routledge Dictionary of Literary Terms. Abingdon: Routledge

Chinweizu, et al. (1980). Decolonization of African literature (vol. 1). Enugu: Fourth Dimension Publisher.

Edwards, Justin D. \& Graulund, Rune (2011). Introduction: Reading Postcolonial Travel Writing. In J. D. Edwards and R. Graulund (eds.), Postcolonial Travel Writing: Critical Explorations, pp. 1-16. UK: Palgrave Macmillan.

Kamp, David (2009). Rethinking the American Dream. Vanity Fair, www.vanityfair.com

Leslie, Debbie (2006). The Global Politics of Contemporary Travel Writing. Cambridge: Cambridge University Press.

Posti, Piia K. (2014). Concurrences in Contemporary Travel Writing. Culture Unbound vol. 6, 1319-1345. Linköping University Electronic Press: www.cultureunbound.ep.liu.se

Ranjan, Priyansh (2015). Edward Said's 'Orientalism': A Post-Colonial Culture Study. IOSR Journal of Humanities and Social Science (IOSR-JHSS) 20 (9), 85-88. doi.10.9790/083720928588

Said, Edward (1978). Orientalism. New York: Pantheon.

Satapathy, Amrita (2012). The Idea of England in Eighteenth-Century Indian Travel Writing. Comparative Literature and Culture vol. 14 (2), 1-8. doi.org/10.7771/1481-4374.1957 
Soumani, Katerina (2012). Travel, Culture, and Society: A Book Review Article of New Work by Andraş and Tötösy de Zepetnek, Wang, and Sun. Comparative Literature and Culture vol. 14 (1), 1-6. doi.org/10.7771/1481-4374.1925

Thompson, Carl (2011). Travel Writing. UK: Palgrave Macmillan.

Wispinski, Matthew (1997). Re-Exploring Travel Literature: A Discourse-Centred Approach to the Text Type. (Unpublished master's thesis, Simon Fraser University). 